\title{
Writing In The Heavenly Language: A Guide To The Works Of David Joris ${ }^{1}$
}

\author{
GARY K. WAITE
}

A lthough a prolific author by Anabaptist standards, David Joris (c.15011556), one of the most notorious religious dissenters in the sixteenth century, left behind a manageable corpus of writings when compared to that of the German Reformer Martin Luther or the Silesian Spiritualist Caspar von Schwenckfeld. ${ }^{2}$ That very few scholars have been willing to analyze Joris' works has therefore less to do with the quantity and more to do with the quality of the writing. From the conclusions of many earlier studies, one would assume that Joris' compositions were uniformly obscure and spiritualistic. ${ }^{3}$ Anyone who has read Joris closely will attest to the difficulty inherent in his writing. Closer examination of these works in their historical context, however, reveals ideological and thematic clarity unique to Joris. This essay, although far from being a comprehensive bibliographic study, will present some clues to discerning which of his works reflect predominantly Anabaptist concerns and which are dominated by a more thoroughgoing Spiritualism. The intention here is to provide a methodology which may prove useful in the organization and classification of the copious Joris material, with the ultimate aim of making the evaluation of his writings less daunting.

Working with existing bibliographic aids, such as A. van der Linde and Hans J. Hillerbrand, as well as the Joris collections housed in the libraries of the Universities of Amsterdam and Basel, it is possible to arrive at an approximation of the number of works Joris authored. ${ }^{4}$ The raw total, however, tells us little except that Joris was a prolific writer. What is essential is an understanding of the changes in Joris' reform thought which were part and parcel of alterations in his life. In other words, the variations in his reform career provide important clues to the meaning of his thought, which in turn can be useful in broad categorization of his output. For purposes of clarity Joris' works can be divided, admittedly broadly but to some degree ap- 
propriately, ${ }^{5}$ into three periods: The first includes the years between 1529 and 1539 when Joris was an active and enthusiastic Sacramentarian and then Anabaptist. Although frequently on the run, during this time Joris was based in his home city of Delft, Holland. The second falls in the time period 1540-1544 during which Joris lived in Antwerp. This was a transitional phase in the prophet's life, when he began to seriously spiritualize his Anabaptist tenets. His ideology in this middle period is best reflected in the first edition of the Wonder Book which probably came off the press in $1543 .^{6}$ The final stage includes the years from 1544 to his death while Joris lived in Basel. In this tolerant South German city Joris moved towards a complete form of Spiritualism, as seen in the significantly revised second edition of the Wonder Book, completed in 1551. Before providing a summary total of Joris' literary achievements, the subtle but important distinctions in his ideology as they appear in these three phases will first be explored.

Already well before the advent of Anabaptism in the Netherlands, Joris had achieved a degree of fame for a published collection of religious songs ${ }^{7}$ and notoriety as a result of a scandalous anticlerical pamphlet for which he was arrested and punished in $1528 .^{8}$ Unfortunately, neither of these is known to be extant. A few of Joris' pre-Anabaptist songs do exist, however, in a later collection of compositions (see below). After he became an Anabaptist leader in the winter of $1534 / 35$, his literary output grew enormously - particularly so after he found the leisure time to write more regularly once he had moved to Basel in 1544. The historian, therefore, has no lack of source material with which to clarify Joris' historical image.

Considering that between 1536 and 1539, Joris was "the most important Anabaptist leader in the Netherlands," 9 it is particularly important to identify the works which came from his quill in those years. They reveal a different spirit from both his Basel works and his Antwerp writings (perhaps best understood as works of a transitional phase). Joris' tracts of 1535-1539 mirror his nearly frantic attempts to keep alive the apocalyptic excitement that had characterized Dutch Anabaptism before the fall of Münster in the summer of 1535. Dulled somewhat by the failure of apocalyptic predictions, the sword of the vengeance of the Lord still threatened the enemies of the Lord's anointed in writings of this period. After 1539, however, eschatological expectations begin to be spiritualized even further and by the 1550 s Joris appears to have been ashamed of his earlier naivete. ${ }^{10}$

Undated works falling into what can be termed his Anabaptist period are therefore not difficult to discover, if one has the patience to wade through 
them. While van der Linde managed to catalogue ten writings from this period, ${ }^{11}$ a more complete listing can now be made.

The only extant works written by Joris before the fall of Münster are his songswhich exist in a collection entitled $A$ Spiritual Song Book. ${ }^{12}$ Joris was not above revising his songtexts in line with later concerns; there is at least one known instance where he toned down radical vocabulary in a songtext. ${ }^{13}$ By and large, however, the songsin this collection remain accurate reflectors of the early period of the Dutch radical reformation. Many of them are intensely apocalyptical and as such, are among the few windows into the mentality of Anabaptists living in the Netherlands during the high point of the Münsterite kingdom. ${ }^{14}$

The rest of Joris' surviving compositions reflect post-Münster concerns. First among these is the tract Of the Wonderful Working of God, written in 1535 in an attempt to account for the failure of Münster and to present a reformulation of Bernhard Rothmann's and Melchior Hoffman's teachings suitable to the new situation. ${ }^{15}$ A further distinguishing mark of this tract is its fairly lucid style and identifiable historical context; even if no date was provided, it would still be apparent that the work belongs to the period shortly after July 1535 . It will presently become clear that such lucidity in Joris' writings is rare indeed.

In December of 1536, Joris experienced two major visions which dramatically altered his sense of mission and in turn his writing style. This change is evident in a long and repetitive tract written immediately and in haste after the revelations, presumably under the direction of the Holy Spirit. More of an oral announcement than a well thought-out literary composition, the 1536 tract was recognized by Joris himself as a decisive document. ${ }^{16}$ While of course there is much continuity between his pre- and post-vision works, in a later work Joris remarked that Hear, Hear, Hear, Great Wonder, Great Wonder, Great Wonder, was his first. ${ }^{17} \mathrm{He}$ perhaps meant by this that it was the first tract to delineate his self-conception as the third David, as the apocalyptical servant of God who would complete the victory of the second David, Jesus Christ, over the final enemy, death. ${ }^{18}$

Shortly after this calling, Joris received another divine mandate to proclaim the message to the remaining Melchiorites (followers of Melchior Hoffman), particularly those in England, Frisia and Germany (Strasbourg). ${ }^{19}$ The unpublished Hydeckel contains many letters from 1537 on which indicate that he took this mission seriously. ${ }^{20}$ Included in this volume are letters to the Strasbourg Melchiorites in 1537. Also present is Joris' correspondence to his supporters in Frisia and Westphalia. Of interest is his recommendation to 
followers near Oldenburg, that they heed the advice of Heinrich Krechting, the leader of the Münsterite refugees in northern Westphalia, before selecting pastors and deacons for their fellowship. ${ }^{21}$ Furthermore, Joris penned several tracts relating to this mission (again under the direction of the Spirit). These include the 1537 An Admonition, in order to Bridle the Tongue, a work intended both to announce his mission and to warn his readers from speaking presumptuously about the things of the Lord. ${ }^{22}$ The contents of this tract lead one to suspect that it was among the works sent by Joris to the Strasbourg Melchiorite leadership, the "elders of Israel" in 1537 and $1538 .{ }^{23}$ Although no dated tracts are known to have been written by Joris in 1538, this year is notable for the manuscript record of the disputation between Joris and the "elders of Israel" held in June of 1538. Not extant in a published form, whether or not this record actually went to press or was even intended for publication is not known. ${ }^{24}$ It is nevertheless an extremely important source not only for its depiction of how Joris publicly defended his teaching and calling, but for its rare insight into the frame of mind of the followers of Hoffman in Strasbourg. ${ }^{25}$

Several works appear from 1539. Those which have been dated include: $A$ very beautiful tract or examination of the enemies of man $;{ }^{26} A$ very beautiful tract on the beauty of the beloved; ${ }^{27}$ An Announcement of the coming of the Bridegroom; 28 "Behold, and wake up my Children", in The third Handbook; ${ }^{29}$ "Behold, a vision, [seen] openly in the daylight, of one who loves the truth and justice of God"; ${ }^{30} A$ very good examination of wisdom; ${ }^{31}$ and The Eight Blessings. ${ }^{32}$ This last work is Joris' written attempt to encourage his followers in the face of the horrendous persecution which they were experiencing, for court records indicate that at least one hundred Davidites were put to death in this year, including Joris' own mother ${ }^{33}$ The fifth work listed, "Behold, a vision," provides an uncommon glimpse into how Joris was viewed by his associates. He was explicitly regarded as a human-divine being and it is necessary to comprehend this attitude on the part of his followers and readers in order to understand both the popularity of Joris' writings and his development of a new, "spiritual language". After all, a person of such exalted status could not be expected to communicate in a common or earthly vernacular. ${ }^{34}$

While this summary includes all the known extant works composed by the Dutch prophet before the decade of the 1540 s, there are several undated tracts that can be safely assigned to this early period. The criteria for this selection have been mentioned above - evidence of intense apocalypticism (still to be fulfilled on earth) and references to specific events and severe persecution. It is therefore possible to suggest that at least the following works belong to Joris' "Anabaptist phase": Of the Principle or Wedding of the Heavenly 
Marriage $;^{35}$ The End Comes, the End Comes over all the four Corners of the Earth ${ }^{36}$ A Blessed Instruction for the Hungering, Anxious Souls, ${ }^{37}$ and How the Believer, who takes to himself a Sister or Wife, should Support her. ${ }^{38}$

These last two cited works appear to be related to Joris' experience at the Strasbourg disputation. A Blessed Instruction is an exceptional work, hitherto unstudied, which contrasts the true, elect Bride of Christ, forced to drink of the cup of bitterness and suffering, with the proud scribes who trust merely in the letter, but not the spirit of the Scriptures. ${ }^{39}$ All religious persons or groups are here criticized for their ignorance of the true message of God: the Monks and Priests have the Word of God, "but look at their righteousness and faith"; the "Martinians" claim to have the gospel and faith, but "look at their fruit"; and even the "Covenanters" (another name for Melchiorites), who "should be the most pious" do not live up to their reputation. ${ }^{40}$ What has caused this disillusionment with the Melchiorites in particular? A clue is found in a very interesting comment that Joris makes regarding Melchior Hoffman:

Think about what kind of people and teachers they are [i.e., those who rely on the literal text] ... they are still children in their understanding. They held Melchior Hofman above everyone, as a servant of the Lord, filled with the Holy Spirit and with all riches of the truth and knowledge of God. Namely, as the true Elijah, Michael, the promised David, the mighty angel of Heaven, whom one must hear and follow. Indeed, the one who was joined with him, namely Enoch, stood far behind him, and will not come nearly as far into the glory as he. But they nevertheless presumed and pretended that they administered the letter to him (Melchior Hofman) but he ministered the Spirit to them. Is that not an abomination and shame? Yes, a terrible defamation by the Saints in Israel ... And although I have said, written and pointed out to them their foolishness more than enough, yet they still will not believe me. ${ }^{41}$

When these remarks are compared to his comments about Hoffman and the Strasbourg Melchiorites made during the Strasbourg disputation, there is little doubt that Joris is here referring to the less than enthusiastic reception which he experienced among the followers of Hoffman in the summer of $1538 .{ }^{42}$ This tract was therefore probably composed shortly after that event.

A similar case can be made for How the Believer. This appears to be the work on marriage that Joris promised to send to the Strasbourg Melchiorite leadership after the disputation. ${ }^{43}$ Furthermore, in 1537 he had sent to them a "long letter on marriage" as well as his response to Johannes Eisenburg's tract on the subject. These two works may have formed the basis for How the Believer. Furthermore, the argument contained herein is an expansion of 
Joris' points found in the Eisenburg letter. If this is indeed the case, then we may have another early pre- 1540 tract. $^{44}$ While several others may be discovered ${ }^{45}$ the aforementioned works help to fill in our knowledge concerning Joris' teaching while an active Anabaptist leader.

Perhaps the most valuable work for our knowledge of Joris' life and even state of mind during his time as a reformer and Anabaptist, is an anonymous biography composed by a close associate of the leader, sometime after Joris' move to Basel. The account is so richly detailed that it is quite likely that Joris himself penned it. At the very least he was personally involved in its production. ${ }^{46}$ In any event, it carries the stamp of autobiography, and its extraordinary insight into Joris' mental and emotional condition during periods of severe persecution makes it one of the most remarkable documents in the field of the radical reformation. ${ }^{47}$

As suggested above, all of these works prior to the Antwerp and Basel periods are relatively straightforward and, compared to his spiritualist writings, easy to comprehend. Furthermore, Joris believed that while the Word of God was formerly spread in the Hebrew, Greek and Latin tongues, the Holy Spirit now preached in Dutch. ${ }^{48}$ Hence the message of God was most easily understood by Dutchmen. Unfortunately for later readers, he also developed his concept of a "spiritual language", of a holy vernacular, which was understood only by a spiritually-enlightened elite. He spelled out this idea in his Clear Report on how Man has fallen from God, which was completed in 1543:

Because many read so quickly that the meaning passes them by, I will, dear reader, warn you not to hold to such a practice or idea, especially in divine matters, in things brought forth by the Spirit with true godly understanding, in a spiritual or heavenly language. For only the spiritual ones will understand the new heavenly language by means of the heavenly birth of God. ${ }^{49}$

His writings, always difficult to understand, became even more turgid, inspiring one well-educated contemporary to remark: "It was difficult for me to understand the meaning of the thoughts because of the terribly obscure and confused style of the writing." 50 Works originating from Antwerp and from the first years in Basel are therefore notable by the continuing Anabaptist motifs and vocabulary, but increasingly spiritualized and shrouded by his use of an elitist "spiritual" language. The most important work of this period is of course the first edition of the Wonder Book. The progression away from his earlier fixation on the nearness of the return of Christ and the final judgement is obvious; Christ would still return, Joris affirms, but his coming would be one noticed only by those spiritually prepared. In other words, even 
the apocalyptical return of Christ had been internalized and its earthly ramifications, so important for Münster, had been defused. ${ }^{51}$

One way to come to terms with the changes in Joris' thought during his Basel residence would be to compare the second edition of the Wonder Book with the first. While such a massive project is beyond the scope of this essay, a starting point might be the examination of Joris' narcissistic attitude concerning the third David. The first edition brought to a climax his self-conception as the apocalyptic agent of God. If by the time of the second edition in 1551 Joris had toned down this belief, then it would be possible to argue that his acquaintanceship with the Basel Spiritualist Sebastian Castellio had been a formative one. ${ }^{52}$

At first glance, the chapters concerned with the subject of the third David appear remarkably similar. On closer examination, however, it becomes clear that Joris had made some quite subtle revisions by 1551 . For example, when in the first edition he announced: "This is the promised, elect David, the authoritative prince"; in the second edition he proclaimed: "This is the principal spirit of power, the promised, elect David." 53 The difference was enough to bring into question whether the promised David was to be identified with a person (i.e., Joris) or with the Holy Spirit. Furthermore, Joris in the later version added a section explaining his current view of the promised David and the kingdom. Here the third David was closely identified with the Spirit, and the kingdom of the promised David was spiritualized to mean little more than the community of those who had experienced the rebirth of Christ. He wrote

concerning this promised Spirit of truth, or David. This one was not proclaimed in this name [i.e., David], but in the true, zealous Spirit, which should begin and end in the truth. For it is certain that the eternally enduring kingdom was not established in the birth of our Lord Jesus, seeing that (as one speaks of a kingdom) it was disturbed by the Antichrist, the scarlet whore ... And the eternally enduring kingdom must remain rigid [and] undisturbed, completely crushing and bringing to nought all previous kingdoms. We clearly see that this has still not happened in our time. For this reason my profession here is that when the true Christ in the eternity is born in us according to the Spirit and truth, this shall be another David according to the Spirit and truth (as was professed and as Peter has testified). Then this eternally enduring kingdom (of which Daniel has spoken) will be established and remain standing firm and undisturbed, as the Scriptures affirm. ${ }^{54}$

While Joris in his later career maintained a doctrine of the third David, he had lessened the implication that he and the third David were the same and 
had instead strengthened the connection between that apocalyptical figure and the Holy Spirit.

We can therefore ascertain subtle differences among the works of Joris' literary corpus which allow us to discern the historical context in which they were composed. While this study is merely an initial investigation, it is now possible to give an approximation of works written in the three identified periods of Joris' career.

There are, therefore, around 241 published works, from short tracts of only a few pages to massive volumes such as the Wonder Book. ${ }^{55}$ Of the undated works, seven are large volumes of collected works, either brief tracts, as in

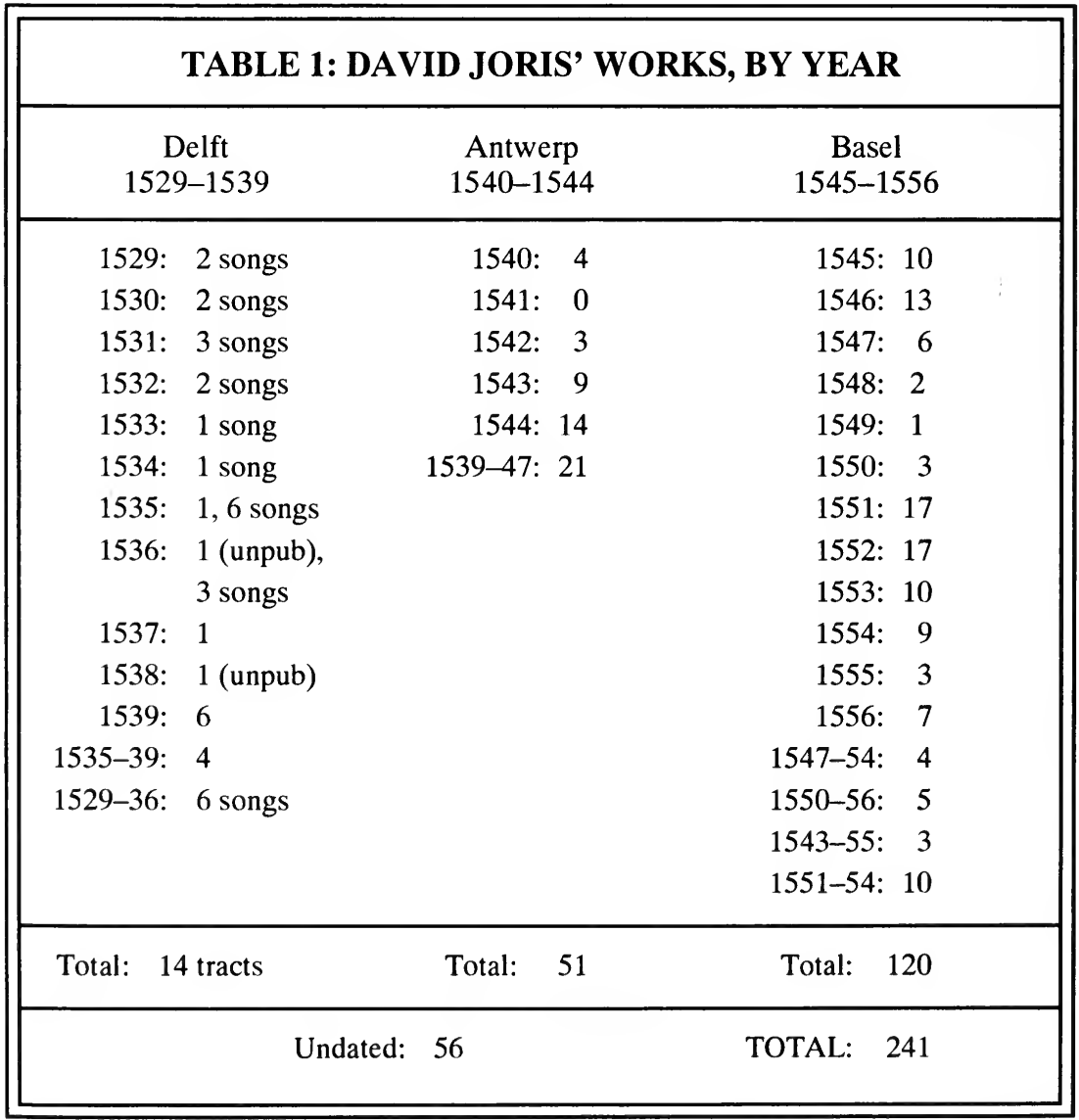


the case of the four Handbooks, or letters, as in the three volumes of correspondence. ${ }^{56}$ Those tracts in the Handbooks which are dated, fall into the following periods: $1539-44-9 ; 1545-1549-4$; and $1550-56-13.57$ Most of the correspondence in the three published volumes was composed after 1546. These volumes together contain 1134 letters. ${ }^{58}$ The Hydeckel contains a further 127 of Joris' missives from the years 1537 to 1543 . For most of these letters, Joris indicated in code the recipient, date and location of composition (see Appendix 1).

Clearly, then, Joris was a prolific writer to match the popularity of his teaching. His following was widespread and numerous; extant are letters to devotees from Emden in the North to Paris in the South, although most adherents were located in the Netherlands. ${ }^{59}$ Moreover, it is known that some of Joris' works were translated into French. ${ }^{60}$ What is remarkable about Joris' group is the relatively high number of the nobility and upper class who associated with the self-acclaimed third David. The Wonder Book in particular circulated freely among members of the social elite and appears to have been published as a result of their sponsorship. ${ }^{61}$ Although we do not possess copies of all first editions, it is not unreasonable to assume that most of Joris' tracts and books were printed during his lifetime. Postulating a conservative figure of 300 copies per print, ${ }^{62}$ there might have been more than 70,000 copies of David Joris' compositions circulating in the Netherlands through the course of the sixteenth century, again not including letters and unpublished works. There is little doubt, then, that even limiting our perspective to literary works alone, Joris was a well-known and influential figure in the sixteenth century. It is possible to conclude that either there were quite a number of Netherlanders who could understand the "heavenly language", or the incomprehensible nature of some of his teaching was sufficient proof to many that Joris was indeed a prophet who, in the words of one of his followers, was "suspended between heaven and earth." ${ }^{3}$ In the minds of his supporters, that most of their contemporaries could not fully understand Joris' words was due, therefore, not to poor style on the master's part, but to the lack of spiritual discernment on the part of unenlightened readers. On the other hand, those who could profitably read his tracts were able to regard themselves as members of an intellectual-spiritual elite, as spiritual supermen. Reasons for his appeal are therefore not hard to find. 


\section{APPENDIX 1 \\ THE RECIPIENTS OF JORIS' LETTERS, 1537-1543 ${ }^{64}$}

\begin{tabular}{|c|c|c|c|c|}
\hline Name & Destination & Date & Source & Folio \\
\hline Mariken Geerits & Schilde & 1543 & Antwerp & $5 r$ \\
\hline Rhaniar Ceindr. & $\longrightarrow$ & Jan.1543 & Antwerp & $5 v$ \\
\hline "Hoort den Geest getuigen" & - & $\longrightarrow$ & $\longrightarrow$ & $6 v$ \\
\hline Derberen Frans' house & Antwerp & Jan.1543 & $\longrightarrow$ & $131 v$ \\
\hline "Neemt waer. Lieve" & $\longrightarrow$ & Mar.1539 & Haarlem & $135 v$ \\
\hline Derberen's house in & Antwerp & Jan.1543 & - & $140 v$ \\
\hline Griete S. & $\longrightarrow$ & Jan.1543 & Antwerp & $142 v$ \\
\hline Lubbert & Freckenhorst & Mar.1543 & Antwerp & $144 v$ \\
\hline Maritgen (young widow) & $\longrightarrow$ & Mar.1543 & Antwerp & $149 v$ \\
\hline Heinrich van Vreeden? & - & Mar.1543 & Antwerp & $153 v$ \\
\hline Margriete the Deaconess & Freckenhorst & Mar.1543 & Antwerp & $156 v$ \\
\hline Jan Roemen & Freckenhorst & Mar.1543 & Antwerp & $158 \mathrm{v}$ \\
\hline Jan Roemen & Freckenhorst & Mar.1543 & Antwerp & $159 v$ \\
\hline Claes van Schiedam & $\longrightarrow$ & 1538 & Delft & $172 v$ \\
\hline Grietgen Peeters & $\longrightarrow$ & 1543 & Antwerp & $173 r$ \\
\hline Agnes van Limburg, Abbess & Freckenhorst & Mar.1543 & Antwerp & $180 \mathrm{r}$ \\
\hline Jan Doels & Emden & 1543 & Antwerp & $186 \mathrm{r}$ \\
\hline "To the Church in" & Emden \& Groningen & Mar.1543 & Antwerp & $203 r$ \\
\hline The Goldsmith in & Groningen & Mar.1543 & Antwerp & $205 v$ \\
\hline $\begin{array}{l}\text { Jan Ruin, Fiman \& } \\
\text { Maritgen }\end{array}$ & Groningen & 1543 & Antwerp & $207 v$ \\
\hline A widow at & Emden & Mar.1543 & Antwerp & $210 \mathrm{r}$ \\
\hline Sinken at & Emden & Mar.1543 & Antwerp & $213 r$ \\
\hline Anna at & Groningen & Mar.1543 & Antwerp & $215 r$ \\
\hline Goosen at & Emden & Mar.1543 & Antwerp & $218 v$ \\
\hline Doede at & Emden & Mar.1543 & Antwerp & $220 v$ \\
\hline Geerit boutemaker & Emden & Mar.1543 & Antwerp & $222 r$ \\
\hline To those of & Oldersum & Mar.1543 & Antwerp & $224 v$ \\
\hline Jacob \& Griete at & Groningen & Apr.1543 & Antwerp & $228 \mathrm{r}$ \\
\hline Lucam Schilder & Groningen & Mar.1543 & Antwerp & $232 r$ \\
\hline Simon Dorsschen & Emden & 1543 & Antwerp & $234 \mathrm{v}$ \\
\hline Mariken Jacobs & - & Dec. 1542 & Antwerp & $236 v$ \\
\hline Hillegont at & Rotterdam & 1542 & Antwerp & $238 \mathrm{r}$ \\
\hline Joestin & Delft & Mar.1543 & Antwerp & $239 v$ \\
\hline
\end{tabular}


Salomon (Willeten)

Grietken Peeters

Grietken Peeters

Jan de Vou

"Exegesis of Romans 7"

To those of

Christoffel \& Hans

Christoffel, Hans \& Refel

Christoffel \& Andries

Christoffel

Christoffel, Anthonium,

Herman \& Hermanum

Christoffel

Jacob van Wien

Christoffel

Geerit Rogge

Dignum

Heinrick Twerner

"To Praise of the Lord"

Jan van Leeuwarden

Herman Dlidorp

"Eeen scalck man verbercht"

Hans Eisenberg

"Eeen ellenden Roep"

"Uprechting der Gemeinte"

"Saluit mein beminde"

"Den onreinen is niet met"

"Inden Name Jesu"

"Emanuel. Neemt waer"

"Dit roept u den Geest"

"Neemt waer. Hoe lange"

Agnes, Abbess of

"Spreect dit dat zyt alle"

Anthonium \& Herman

To those of

To beloved brothers

"Behold Brothers"

"Siettoe mein Broederen"

Jacob inde Kelder
Schilde

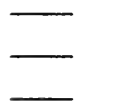

Giethoorn
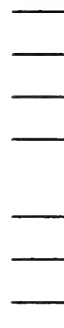

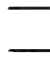

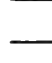
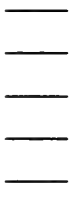

Strasbourg

(Strasbourg?)

Oldenburg
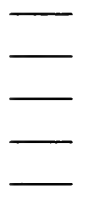

Freckenhorst

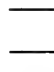

Leeuwarden

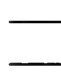

Groningen

\section{3}

Jan. 1543

1543

1543 ?

$1537 / 38$

1539

1537

1537

1538

1538

1538

1540

$1537 / 38$

1540

1540

1537

1537

1537

1539

1538

1537

(1537)

1537

1537

1537

1537

1538

1537

1538

Apr.1540

?

Mar. 1540

ca. 1540

1539

1537

Dec.1539

ca. 1540

$1539 / 40$
Antwerp 240v

Antwerp 243v

Antwerp 244v

Antwerp 248v

Delft 250r

$265 \mathrm{v}$

Delft $267 \mathrm{v}$

Delft 273v

Delft 275v

Delft 278r

Delft 279r

- 280v

Delft 281v

Antwerp 282v

Antwerp 284r

Delft 287r

Delft 291r

Delft 294v

$297 \mathrm{r}$

Delft 298r

Delft $304 v$

$321 \mathrm{r}$

$330 \mathrm{v}$

$335 \mathrm{v}$

$336 \mathrm{r}$

$336 \mathrm{v}$

$340 \mathrm{r}$

$342 \mathrm{v}$

$344 \mathrm{r}$

$346 \mathrm{r}$

$354 \mathrm{v}$

$358 \mathrm{v}$

$362 \mathrm{v}$

$365 \mathrm{v}$

$367 \mathrm{v}$

370r

$372 \mathrm{r}$

$375 \mathrm{v}$ 
Emanuel. Ick wensche"

Griete Jacobs inde Kelder

Geerit Roggins

Jacob of Groningen's wife

Jacob inde Kelder

The Gemeinte

Emanuel Die H. is met ons" Deventer

J. \& H.

Mariken Herman Diericks

Grietken Gasuelt Jacobsdr.

Fiken Goutsteens

Griete van Heeskering

Janneken \& Swaenken

Hacfort's maid

Dierckin Modders in the

Heinrick Moddersdr.

Maerte van Modder

Christoffel \& Andries

Joest Wever

Jansen

Meincheut, a teacher

Aeltkin Antonis

Huigen's wife in the

Hillegont at

Meinard Claesson

"Maect v rekenninge"

"Neemt waer, mercter wel"

"Klaechliedeken"

"of iemant vry huywen"

Jan Jacobs' house

Grietken Peters

Siken at

Jan van Liewoort

Jorien Ketel

Jorien Ketel

Hans van Leeuwarden

Sibrandum, a Preacher

Aernout Gisbrechtes

Dr. Hieronimus

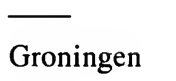

1537

1539

1539

ca.1539

Groningen

1541

1537

Apr.1543

Jun.1543

Jun. 1543

Jul.1543

Jul.1543

Jul.1543

Aug.1543

Aug.1543

Aug.1543

Aug. 1543

Aug. 1543

Groningen

Groningenland

Groningen

Wik

Rotterdam

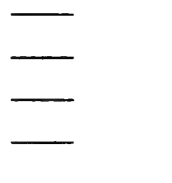

Amsterdam

Delfsgauw

Deventer

Deventer

Appingendam

Groningen

Emden

Aug. 1543

Aug. 1543

Mar.1543

Apr.1543

Apr.1543

Apr.1543

Mar.1543

$1538 / 39$

$1538 / 39$

1537

Apr.1543

Apr.1543

1542

May 1543

Jun.1543

1542

Aug. 1543

Oct.1543

Oct.1543

Oct.1543

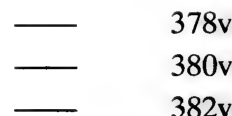

Groningen $383 \mathrm{r}$

Antwerp 384v

$397 \mathrm{r}$

Schilde 399v

Antwerp 401r

Antwerp 402v

Antwerp 404r

Antwerp 405r

Antwerp 406r

Winter 1542
Antwerp 407r

Antwerp 408r

Antwerp 409v

Antwerp 411r

Antwerp 413v

Antwerp 415v

Antwerp 416v

Antwerp 421r

Antwerp 423v

Antwerp 425r

Antwerp 427r

Antwerp 428v

- $429 \mathrm{v}$

$431 \mathrm{r}$

$432 \mathrm{v}$

$434 \mathrm{v}$

Antwerp 436v

Antwerp 440r

Antwerp 441v

Antwerp 445r

Antwerp 447r

Antwerp 448v

Antwerp 449v

Antwerp 451r

Antwerp 454r

Antwerp 456v 


$\begin{array}{lllll}\begin{array}{llll}\text { To Modder's House } \\ \text { Jacob Hacfort \& }\end{array} & \text { Appingendam } & \text { Oct.1543 } & \text { Antwerp } & 458 \mathrm{r} \\ \text { Heinrick Goutsteens } & & & & \\ \text { To the Gemeinte } & - & \text { Oct.1543 } & \text { Antwerp } & 460 \mathrm{r} \\ \text { Frans van Wesel } & - & \text { Oct.1543 } & \text { Antwerp } & 460 \mathrm{v} \\ \text { Hans van Leeuwarden } & - & \text { Oct.1543 } & \text { Antwerp } & 461 \mathrm{v} \\ \text { Griete Jacobs } & - & \text { Oct.1543 } & \text { Antwerp } & 462 \mathrm{v} \\ \text { Anna in } & \text { Emdenland } & \text { Oct.1543 } & \text { Antwerp } & 463 \mathrm{v} \\ \text { Cornelis Claesson } & \text { Deventer } & \text { Sep.1543 } & \text { Antwerp } & 465 \mathrm{v} \\ \text { To his house } & \text { Antwerp } & \text { Nov.1543 } & \text { Antwerp } & 469 \mathrm{v} \\ \text { To his house } & \text { Antwerp } & \text { Nov.1543 } & ? & 472 \mathrm{r} \\ \text { To his house } & \text { Antwerp } & \text { Nov.1543 } & ? & 475 \mathrm{r} \\ \text { Mr. Jan de scrivere } & \text { Antwerp } & \text { Aug.1543 } & ? & 476 \mathrm{r} \\ \text { Mariken Jacobsdr. } & - & \text { Dec.1543 } & \text { Antwerp } & 488 \mathrm{r} \\ \text { Marioen's house in } & \text { Antwerp } & \text { Dec.1543 } & ? & 488 \mathrm{v} \\ \text { "Een vrage vnde Leeringe" } & - & \text { Summer } 1538 & \text { Delft } & 490 \mathrm{v} \\ \text { "Wten monde stemmelyc" } & - & \text { Aug.1543 } & \text { Antwerp } & 493 \mathrm{v} \\ \text { "Gebet tot G. dagelycks" } & - & 1543 & - & 494 \mathrm{v} \\ \text { "Alle wat wysheit begrypt" } & - & 1543 & \text { Antwerp } & 495 \mathrm{r}\end{array}$

\title{
APPENDIX 2
} LEONARD VAN DAM'S VISION OF THE HEAVENLY MAN ${ }^{65}$

\author{
A vision of one (named Leon[ard] von Dam) \\ who loves the truth and justice of God, \\ which he has seen in the daytime \\ during the course of the month of May \\ or beginning of June 1539 .
}

Sitting up in the attic in a house it happened that the Spirit of God came suddenly upon a man named David and he began to speak of the power and word of his God, just as the Lord placed into his mouth. When I heard these words they were inserted into my innermost being, so that the heart and mind of my soul were opened up like a rose. I then could not contain the life and joy of my innermost spirit. I cannot describe this [joy] in words, but it remains with me as unspeakable. And behold I was compelled to stop my work. But I was troubled about this and continued to work in order to overcome my laziness and weakness, although I was pressured to stop. Finally there was a inspiration given to me by the voice of the Spirit, without my advance knowledge or advice, namely in this fashion: "Truly you have heard today (through the living conversations which have proceeded from David's mouth) [and] 
you have listened to, seen, tasted and felt Jesus in his living, spiritual, ${ }^{66}$ true nature, standing at the right hand of God in heaven. Even more truly than had Stephen, Acts $7[: 18]$. Or like Isaiah, who said in Isaiah 6[:1-3], when he saw the glory of God sitting on his seat and throne: "I am a man of unclean lips". Read and speak freely, without timidity also in this way, that you too are a man of unclean lips, and after this you will see in a living fashion [and] in the innermost parts of your heart the majesty of God. After this it was shown to me from the Spirit, that I should read Isa. 6 and Acts 7. I did not know what I would find written there, but I thought, what can it be? At the same time I was full of a living fire and burning in my innermost being, so that I did not know how or what was happening in me. For I was young and did not know the Spirit and in my weakness I could not express what was happening to me. I saw myself as too small and unworthy to speak like a man of God about the exalted word of the Spirit. The Spirit, however, allowed me no rest, but spoke as loudly to me as if it had occurred through a human's mouth, that I should go downstairs. I could neither sleep nor rest, neither in the evening nor night, until one summer afternoon, around three or four o'clock, when I answered and said: "Lord, you know what the situation is here and the reason why I cannot go downstairs." 67

This had happened five or six times when the woman of the house (knowing of it) came up to us in the morning, and said, is anyone up here who wants to come down? You can do so, for the people have departed. About this I was full of amazement and decided to go into the hall or room. When I now had gone in and out of the room five or six more times, I finally stopped and stood there in the middle, and a voice said distinctly to me: "Stand and behold". Then I stood with my face towards the wall and away from the light and I saw a naked man, standing before me, also facing away from the light towards the wall, for I saw him only from behind. He stood with his feet upon the surface of the earth, which was amazing to me. Then the Spirit spoke again to me: "Behold". Trembling, I looked and watched as the man quietly sank down, with his feet gradually descending until his head had also gone under and disappeared. I then saw the earth neither opened nor closed. The voice of the Spirit spoke again: "Behold". I then saw the same naked man under the earth just as clearly as I had seen him above the earth. I therefore became dismayed and frightened, and asked in my heart, what does this man rest on; does he stand on his feet or on his head? I observed that he was suspended between heaven and earth, as I have told you, and he moved as a bird does in the sky. But so that you will understand me, he was in the earth, as I have said to you. Then the Spirit or the voice answered me: "His feet stand upon nothing, and rest upon no outer thing, but he is suspended, for where he is, there is an eternal abyss." Thereupon he called me to look again. Then I saw the same naked man growing or rising out of the earth just like a flower or plant does. But then I saw all of this from behind him. The head came up first, then afterwards the neck, then the shoulders, arms, hips, legs, and gradually the feet, all slowly or little by little. 
Take note. The head came up first, then afterwards the neck, so that he once again stood up completely as before upon the earth. I then wanted to touch him, to see if he was living or dead. But such was not permitted to me, for the Spirit answered me: "He is still dead and not yet living." Then I looked at his feet and I became aware that they touched the earth and became impure from it. But from the feet up the body was so pure, beautiful and shining, that one had never heard of nor seen of such a clean and majestic image of a man. Furthermore, my eyes fell once more upon the feet and I saw that they were now also pure and beautiful from the earth, for the earth or impurity had disappeared completely from them. And behold, I saw the life enter him; first his hips were pulled to and fro from behind, just like a man or beast that has first been killed and yet lays and wriggles, so that his veins and sinews ${ }^{68}$ were pulled to and fro, as is easy to comprehend. A little later he lifted up his arms and let them down again; then he shifted or moved his whole body, so that he now was thoroughly alive. Finally he lifted a leg up from the earth, or stretched it forward, then the other, and set them down again. See, after this he turned completely around with his face towards mine and against the light, and his face shone like the sun. So bright [was it], in fact, that one cannot describe it. He also had a beautiful red beard and he came walking towards me, as if he would go right through me. ${ }^{69}$ Whether he went through or around my body, I do not know. But when he came up to walk to me, I was so amazed and frightened in the appearance of his movement, it was as if I had been outside of my body, standing however upon my feet. I cannot write nor describe this [adequately] with the quill. He was also so large and wonderful, so mighty and frightening, that he feared no one. He furthermore saw perfectly, that all great rulers, lords, princes, dukes, indeed, the kings and emperors of this world were in his eyes as worms upon the earth are commonly regarded by men. As worms, which have only a little movement, not even as the beasts, fish or birds, I say, of which no one fears to tread upon or near them, killing them or letting them live. Yet even more insignificant than these were all men, both small and great, strong or sick, noble or common; all swept away by a wind.

When I now wanted to look at him, he was gone and I saw him no more. Then the Spirit spoke to me: "That is God, the Messiah, the new Creature, the first true man of God from heaven." The name of the person, which was pleasant to me at that time, I will still keep secret, it was very well known to me. He will, according to the word, be even more heard, known and loved at the right time. I did not relate any of this for seven or eight days afterwards, until it finally broke out of my heart. I am also certain that this vision came right from God. Moreover, I desired to reveal or bring it to them, for even as I had seen it outwardly, so I saw it also according to the Spirit. ${ }^{70}$

\section{University of New Brunswick}




\section{2 / Renaissance and Reformation}

\section{Notes}

1 The author wishes to thank Dr. Piet Visser, Curator of the Mennonite Archives, the University of Amsterdam (hereafter Amsterdam), as well as the staffs of the manuscript departments at the University of Amsterdam (1988 and 1989) and the University of Basel (1986) for their friendly and efficient service. Thanks are also due Prof. C.J. Dyck (Associated Mennonite Seminaries) who suggested that I undertake this study and Ms. Colleen A. Johnston (Waterloo) for her helpful editorial suggestions.

2 Schwenckfeld wrote over 1200 tracts and treatises; see E.J. Furcha, "Of Songs and Chants and Religious Rants. Late Sixteenth Century Hymns and Spiritual Songs," Renaissance and Reformation/Renaissance et Réforme, XI (1987), 90. Luther's works are collected in 63 volumes in the Weimar edition (100 including letters, Bible translation and Table Talk) and 61 in the American edition. For Joris' life and work, see Gary K. Waite, David Joris and Dutch Anabaptism, 1524-1543 (Waterloo: Wilfrid Laurier University Press, 1991).

3 James M. Stayer has confirmed the turgid nature of Joris' writing style, "Davidite vs. Mennonite," Mennonite Quarterly Review, LVIII (1984), 462. Roland Bainton's study of Joris, while still the classic in the field, had a tendency to blur the distinctions in his thought. See Bainton, David Joris. Wiedertäufer und Kämpfer für Toleranz im 16. Jahrhundert (Leipzig, 1937).

4 Van der Linde, David Joris. Bibliografie (The Hague: Martinus Nijhoff, 1867), hereafter vdL. Available in The Radical Reformation Microfiche Project, Section I, Mennonite and Related Sources up to 1600. (Inter Documentation Company, AG, Zug, Switzerland), no.400, (Hereafter MF); Hillerbrand, A Bibliography of Anabaptism, 1520-1630 (Elkhart: Institute of Mennonite Studies, 1962). See also A.M. Cramer, Bijvoegselen tot de Levensbeschrijving van David Joris (Leiden, 1844); H.C. Rogge, "Een Band met tractaten van David Joris," originally in Bibliographische Adversaria, new series, I, in MF 424; Bainton, David Joris; Wouter Nijhoff \& M.E. Kronenberg, eds., Nederlandsche Bibliographie van 1500 tot 1540 (The Hague: Martinus Nijhoff, 1923). Several published works were unknown to van der Linde as was the Jorislade, a fifteen volume collection of manuscripts and published works in the University of Basel. There is need for a more complete and up to date critical bibliography.

5 Joris, like Melchior Hoffman and Bernhard Rothmann, divided history into three periods: the age of the Father (the Old Testament period) as the first; the age of the Son (the rise and fall of the Church) as the second; and the new age of the Spirit (beginning with their own day) as the final stage. For Joris, see Van die Heerlijcke ende Godlijcke Ordeninge der Wonderlijker werckinghen Godes/die na sijn eygen Beeld alle dinghen in Dryen wel geschapen ende gemaeckt heeft (n.p., 1535, reprinted 1614), vdL no.99, MF 400. The tradition of this perspective can be traced to the twelfth century Calabrian monk, Joachim of Fiore. See Bernard McGinn, ed., Apocalyptic Spirituality (New York: Paulist Press, 1979).

6 See S. Zijlstra, Nicolaas Meyndertsz van Blesdijk. Een bijdrage tot de Geschiedenis van het Davidjorisme (Assen: Van Gorcum, 1983), 62.

7 The collection must have appeared before his arrest in 1528. See Nicolaas Meyndertsz van Blesdijk, Historia vitae doctrinae ac rerum gestarum Davidis Georgii haeresiarchae (Deventer, 1642), 15. 
8 Paul Fredericq, ed., Corpus documentorum Inquisitionis Haereticae Pravitatis Neerlandicae, IV (The Hague: Martinus Nijhoff, 1889-1900), 349f. Unfortunately, only brief excerpts from the pamphlet survive in the court records. The punishment involved both torture and banishment.

9 Zijlstra, "David Joris en de Doperse Stromingen (1536-1539)," in M.G. Buist, et al, Historisch Bewogen (Groningen: Wolters-Noordhoff, 1984), 125-38.

10 It is probable that his failure to win to his side the Strasbourg Melchiorites during his meeting with them in 1538 was a crucial factor in his disillusionment. On their part, the Strasbourg leaders were also disillusioned by Joris' intransigence and narcissistic claims. See Werner O. Packull, "Peter Tasch: From Melchiorite to Bankrupt Wine Merchant," Mennonite Quartery Review, LXII (1988), 276-95.

11 For three of these van der Linde relied on Cramer's list.

12 Een Geestelijck Liedt Boecxken, reprinted as Mennonite Songbooks, Dutch Series, I (Amsterdam: B. de Graaf, n.d.). An attempt to provide modern harmonies for the songsis made by G.C. Hoogewerff, Liederen van Groot-Nederland. Een Geestelijck LiedtBoecxken (Utrecht: Koninklijke Vereniging, Het Nederlandsche Lied, 1930). Those that are dated fall between 1529 and 1536.

13 This case involved the songof Anna Jans, a wealthy and zealous supporter of Joris who wrote her songin 1536 probably with Joris' help. Werner O. Packull, "Anna Jans of Rotterdam, a Historical Investigation of an Early Anabaptist Heroine," Archiv für Reformationsgeschichte, LXXVIII (1987), 147-73.

14 The main source for Münster Anabaptism is the collection of the Münster propagandist Bernhard Rothmann's tracts. These are in the critical edition edited by Robert Stupperich, Die Schriften Bernhard Rothmanns (Münster: Aschendorffsche Verlagsbuchhandlung, 1970). Unfortunately, few works written by Dutch Anabaptists during this critical time survive. For one example, see Gary K. Waite and Samme Zijlstra, eds., "Antiochus Revisited: An Anonymous Anabaptist Letter to the Court at the Hague," to be published in the Mennonite Quarterly Review.

15 Van die Heerlijcke. The microfilm copy is missing fols. 78v-79r. For an analysis of this tract, see Waite, David Joris, 89-106.

16 Hoert hoert hoert, Groot wunder/groot wunder/groot wunder (n.p., n.d.), MF400, vdL no.163. The version consulted by van der Linde was a reprint from 1610; the microfilm version is clearly an earlier edition from either Albert Pafraet's or Dirck von Borne's press, Joris' major printers in Deventer. The original edition is in Amsterdam, II 1976a. Although undated, the tract must have been completed by late December 1536 or January 1537. Joris' anonymous biographer explained that "when he awoke or came to himself, he was exhausted, as if he had run for 2 miles, he was breathing so heavily from exhaustion. He seized immediately feather and ink with both hands, and wrote while still standing ..." and continues to quote verbatim the first few pages from Hoert, hoert, hoert. "David Joris sonderbare Lebensbeschreibung," Unpartheiische Kirchenund Ketzer Historie (Frankfurt: 1729. Reprinted by Hildesheim: Georg Olms, 1967), 713. The 1610 edition has at the end "uitgegheven 1539," which is incorrect as a date of composition. It may, however, be the date of a reissue, for the seventeenth century version has a different title page, beginning "Hoort die stemme des Heeren/ die voor dat aenghesicht des Heeren wtgaet". In Amsterdam, 2494, B18. 


\section{4 / Renaissance and Reformation}

17 See vdL, 44. Joris reiterated this in another work, Neemt waer. Dat boeck des levens/ is mi gheopenbaert (n.p., n.d.), fols. $2 \mathrm{v}-3 \mathrm{r}$, vdL no.177. Interestingly, Joris' use of the phrase "hoert, hoert, hoert" here and in other works may take its cue from city heralds who appear to have used the imperative expression to call attention to their announcements. An example of this is found in a Chamber of Rhetoric play from the first half of the sixteenth century, wherein a herald enters the stage, sounds his trumpet and exclaims "Hoort, hoort, hoort, nu luijstert nae mijn ghescal". W.M.H. Hummelen and C. Schmidt, Naaman, Prinche van Syrien (Zutphen: B.V.W.J. Thieme \& Cie, n.d.), 62. Rhetoricians drew much of their material from daily life.

18 See especially fols. $30 \mathrm{r}-33 \mathrm{v}$.

19 "David Joris sonderbare Lebensbeschreibung," 715.

20 It is found in the Jorislade, vol.9. Unfortunately, fols. 6-130 are missing from the manuscript at Basel. For a list of recipients of Joris' letters, see Appendix 1.

21 The letters to Strasbourg included: "Den wisen zi dit gescreuen: den onwetenden en Lates niet al weten: Wilt dat Heilichdom niet den honden geven: noch u Peerlen, unde Rosen vor die verckins stroyen. Och letter up. Antwoort up Hans Eysenburchs Vorreden," fols.305-21 and possibly "Eeen ellenden Roep," which immediately follows the response to Eisenburg and is dated 1537. The letter to his supporters near Oldenburg is entitled "Vprechtinge der Gemeinten," begins on fol.331r and is also from 1537. It was intended to prepare the way for his visit to northern Westphalia in the spring of 1538, where he temporarily gained the allegiance of the Münsterites there. See Waite, David Joris, 120-22.

22 Eene onderwysinge ofte raet/ omme die gedachten in den toem tho brengen, MF 400, $\mathrm{vdL}$ no.1, but mistakenly listed as no.167 in the microfiche collection.

23 Joris remarked to the Strasbourg Melchiorites that he had "sent two letters here to Strasbourg in the beginning of 1537 where they were a little corrected and improved ... After this they received two or three printed booklets, also a long letter on marriage, and a booklet written on marriage against a booklet of Hans Eysenburch, made by Mel[chior] H[offman]." Marc Lienhard, Stephen F. Nelson and Hans Georg Rott, eds., Quellen zur Geschichte der Täufer, Vol.15, Elsass III, Stadt Straßburg 1536-1542 (Gutersloh: Gerd Mohn, 1986), 163.

24 Called the "Twistreden" (Disputation), the critical edition of which is in ibid., 156-231.

25 For an analysis from the perspective of the Strasbourg Melchiorites, see Klaus Deppermann, Melchior Hoffman, Social Unrest and Apocalyptic Visions in the Age of Reformation, trans. by Malcolm Wren and ed. by Benjamin Drewery (Edinburgh: T. \& T. Clark, 1987), 366ff. For studies of Joris' role in the debate, see Zijlstra, "David Joris," and Waite, David Joris, 132-40.

26 Een seer schone tractaet off onderwijs van mennigerley aert der menschen vianden (Deventer, Albert Pafraet, 1539), vdL no.3. Not in the MF collection, but available in Amsterdam, 2494 B18.

27 Een zeer zuuerlyck tractaet van de lyeffde schoenheyt (Deventer: Pafraet, 1539), vdL no.166, but listed as no. 1 in the microfiche collection, MF 400.

28 Eyn wtroepinge van der brudegoms kompst (n.p., 1539), vdL no.2, not in MF, but available in a 1616 edition, in Amsterdam, 2497, B19. 
29 "Neemt waer/ ende waeckt op myne Kinderen," vdL no.222, 1.

30 "Neemt waer een Gesicht, van eenen die de Waerheyt ende dat recht Godts lieft, openbaer by dage" (n.p., 1539), vdL no.4. While this work was evidently published, it exists only in a German translation as part of the "David Joris sonderbare Lebensbeschreibung," 730-31. The vision was actually experienced by one of Joris' closest associates, Lenard van Dam, but was probably written or at least edited by Joris. For a translation, see Appendix 2.

31 Seer goet onderwysinge der wijsheit ... Beyde vor Ouden ende Jongen (Deventer: Pafraet, 1539), vdL no.167, MF 400.

32 Die Acht Salicheden (n.p., Sept. 1539). Not catalogued by van der Linde nor by Hillerbrand, but listed by Cramer as \#3. Available in Amsterdam, 2497 B19.

33 His wife was also arrested at Utrecht, but while thirteen of her compatriots were executed, she was released. See Waite, "The Methods of Survival as practiced by an Anabaptist Fugitive, David Joris," Mennonite Quarterly Review, LXI (1987), 46-57. Karel Vos earlier edited a letter written by Joris in 1539 to encourage "a brother in his fear" during the intense persecution. "Brief van David Joris, 1539," Doopsgezinde Bijdragen, LIV (1917), 163-65.

34 See Appendix 2.

35 Des Hemelschen Ehestands beginsel of trowinghe/ die Belofte of vereeniginge des herten (n.p., n.d.), again part of Amsterdam, 2497 B19 and not in van den Linde nor Hillerbrand. It can be set to the early period by Joris' instruction to his readers, the "oppressed, poor, abandoned people" (fol.24v) to come to the "glorious freedom of the children of God" (fol.24r); the first phrase referring to a period of intense persecution and the second is a nearly verbatim citation from Rothmann, "Verborgenheit", in Stupperich, Rothmanns Schriften, 296-7.

36 Dat eynde coemt/ dat eynde coemt ouer alle die vier hoecken der aerden (n.p., n.d.), $\mathrm{vdL}$ no.165, listed as vdL no.166 in MF 400. Again, the nature of the apocalyptical message here confirms an early date.

37 Een salighe Leeringe voor die hongherighe bekommerde Zielen (n.p., n.d.). Not listed in either van der Linde nor Hillerbrand. In Amsterdam, 2497 B19.

38 Hoe sich die gelouighe, die een suster ofte vrouwe tot hem neempt, draghen of sy beyde haer tegen den ander hebben sullen. Wat houwen ende trouwen te seggen: ende waer toe die Echt nut goet ende orber van $G$. ingheset is (n.p., n.d.). First discovered by Rogge, "Een Band," 10. This work is neither catalogued by van der Linde nor included in MF, but is listed in Hillerbrand as 2926a, and available in Amsterdam, 2494 B18.

39 He writes that the "Bruyt Christi ... oock van den selven Wijn die Bitterheyt des Kelcks drincken/ ende mit sulcken ghedranghe/ door dat lyden ende banghicheyt in die bitterheyt des Doots/ onder dat Doopsel duypelen of duycken moet/ daer haren Heere ende Meyster (dat Hooft) in voorgetreden heeft" (fol.111v).

40 The whole passage is noteworthy: "Desghelycks die Monicken ende Papen/ hebben oock die Heylige Schrift/ aensiet hare rechtvaerdicheyt ende Geloof: Die Martinianen ende alle die haer dat Euangelium beroemen/ ende dat Gheloove seggen te hebben/ aensiet eens hare Vruchten: Die Bondgenooten/ die de alder-vroomste solden sijn/ ende haer sonderlinghe holden mit Christo verghadert te wisen/ die mach men oock aen hare Woorden ende besneden herte wel kennen" (fol. 120v). 


\section{6 / Renaissance and Reformation}

41 The original reads: "Ghedenckt/ wat dat voor Luyden ende Leeraers waren/ die haer belyden ende bekennen moesten ... noch kinderen in't verstant te wesen: Die Melchior Hofman boven een yeghelijck hielden een knecht des Heeren/ ver8vult mitten Heyligen Geest ende mit alle Rijckdommen der Waarheyt ende der kennissen Godes/ als Namelijck/ voor den rechten Elias/ den Michael/ den beloofden David/ den stercken Engel van den Hemel/ die men hooren ende volgen moeste/ Ja dat die gene die hem toegevoeght was/ Namelijck Enoch/ al verde achter hem stonde/ ende niet so verre in die Heerlijckheyt sal komen als hy/ ende haer nochtans vermeten ende voorghegeven hebben/ dat sy hem (Melchior Hofman) die Letter/maer hy haer den Gheest aendiende. Is dat niet een grouwel ende schande/Ja een groote lasteringe by den Heyligen in Israel/ ... Ende alhoewel ick haer genoegh gheseght/ geschreven/ ende hen hare dolinge aengewesen hebbe/ so en hebben sy my nochtans niet willen ghelooven" (fols. 123v$124 r$ ).

42 See in particular, "Twistreden," fols. 34r-36v; 48vff; 95rff; 97ff.

43 "Twistreden," fol. 107r.

44 Furthermore, Hillerbrand suggests it was printed in Deventer c. 1540 and the print type belongs to a number of tracts printed by Deventer presses between 1539 and 1547. That the dated works in the volume of which Hoe sich die gelouighe is a part (Amsterdam, Ned. Inc. 302) run from 1537 to 1543 , may also imply an early printing.

45 Another tract from Amsterdam, 2497 B19 could be a candidate: Van den Geest ende Gave der Ootmoedicheyt (n.p., n.d.), with its reference to proclaim the message before "den Dach des Oordeels", appears early, but it is not possible at the present state of research to discern whether it came sometime before or after 1540 .

46 While not extant in the original Dutch, it was discovered by Gottfried Arnold in the eighteenth century and included, in German translation, in his Unpartheiische Kirchenund Ketzer Historie. A likely scenario is that Joris' secretary, Heinrich von Schor wrote down the stories as Joris narrated them and filled in the details with sections from his tracts and with personal commentary. I am in the process of preparing a volume of translations of Joris' early writings which will include this biography.

47 The other major contemporary account of Joris' life is by his son-in-law, Nicolaas Meyndertsz van Blesdijk. This biography, the Historia vitae, written well after Joris' death and Blesdijk's defection from the movement, is discussed by Zijlstra, Blesdijk, 165-71 and Stayer, "David Joris: A Prolegomenon to Future Research," Mennonite Quarterly Review, LVI (1985), 358. The critical Historia vitae provides a necessary corrective to the often uncritical anonymous account.

48 For more on Joris' concept of Dutch as the language of the Holy Spirit, see Gary K. Waite, "The Holy Spirit Speaks Dutch: David Joris and the Promotion of the Dutch Language, 1539-1545," forthcoming in Church History.

49 Clare Berichtinge, Hoe die Mensch van Godt ghevallen ende jn wat manieren hy weder tot Godt gebrocht wert een claere ende leuendige opsluytinge (n.p., 1543), fol. 97v, vdL no.17, not in MF. In Amsterdam, MA 376, reprinted in 1614. The original reads: "diewijl daar veele sijn, die so haast sy wat lesen, dat verstant daer af al meenen wech-te-hebben, heb Ick $v$ (Beminde Leser) derhalven willen waerschouwen, dat niemant sich vergrypende sulcks beroeme of duncken late, by sonder in Godlijkcke saecken, in een Gheestelijcke tonghe ende Hemel-lantsche spraacke, door den Geest 
mit waren verstande godlijck voortgebracht. Diewyle dan die Gheestelijcken alleen, die Hemelsche nieuwe tonge vanden Hemelschen Geborenen Godes verstaen ... " $\mathrm{He}$ continues "mit sijn eyghen ooge, geest ende verstant moet ghesien ende ghevattet werden, Godt in sijnder Waarheyt beyde te soecken ende te vinden is, derhalven moet het te meer benaerstigher, ja mit sijns selfs ghesicht (dat is, hem ghelijck sijnde) aenghesien, mit vlijt ghelesen, innerlijck, ghestlijck verstaen, krachtich mitter daat bewesen sijn. Want men moet dat licht in't licht, God in God, Geestlijcke dinghen in den Gheest sien, soeken ende vinden ..." (fols. 97v-98r).

50 The Evangelical Rentmeester of Groningen, Hieronymus Wilhelmi, writing to Junker Karel van Guelders after the latter had sent him a copy of Joris' Twonder Boeck. The letter is found in Blesdijk, Billijcke Verantwoordinge ende eenvoldighe wederlegginghe Nicolaes Meynertsz van Blesdijck op eenen scheltlasterighen brief door doctorem Hieronimum Wilhelmi ... int jaer 1544 (n.p., 1610), fol. 102v.

51 He stated: "I say to you, inside, in your innermost heart will it [the day of the Lord] come upon you. Your conscience will be examined, your words, works and thoughts be weighed and measured, where you are accused by yourself ... For in this way exists his coming" (Twonder Boeck, fol.vii[v]).

52 Most Spiritualists rejected any notions which might lead to further sectarianism. Sebastian Franck, for example, remarked that "at the present time not a single true and natural word of the Lord Jesus Christ, the Son of God, is acknowledged on earth, yea, that no one has begun to recognise the righteousness of faith." "Letter to John Campanus" in George H. Williams and Angel M. Mergal, eds., Spiritual and Anabaptist Writers (Philadelphia: The Westminster Press, 1957), 158. For more on the relationship between Joris and Castellio, see Waite, David Joris, 181-82.

53 Twonder Boeck (Deventer, Dirk von Borne, 1542/3), part I, fol. 51v: "Dit is den beloofden wtuercoren Dauidt/ die gheweldige Vorst"; (n.p., 1551), part I, fol.57r: "Dit is den principaelsten Geest der kraft/ den beloofden wtverkoren David die geweldige vorst."

54 Ibid (1551), part I, fol.58r. The full citation reads: "Dan siet/ hier mach Ick metten kop niet doorvaren/ mijn verstandt wie der Haen ouer die kolen/ niet verbyloopen/ Namelijck/ of dat woort des Rijcks sich niet wyder wtstreckt van desen beloofden Geest der Waerheyt oder Dauid/ dat het oock niet in desen Name/ sonder inden rechten yuerighen Gheest/ die daer door wtgesproocken werdt/ solde na der Waerheydt eewelijck beghinnen vnde voleynden. Want t'is kenlijck/dat het eewich werende Rijck/ niet in der geboorten ons Heeren Jesu opghericht en is: Nadien dat (als ment voor een Rijck wolde wtspreecken) door den Antichrist/ die Scharlaken Hoer verstoort/ghen verby Babylonien wech gevuert is: Vnde dit eewich werende Rijck/ most onuerstoort stijf blyuen/ alle vorighe Koninckrijcken vermalen vnd gantsch te niet doen/ welck wy opentlijc sien/ dat in dier tijt/ vnd noch niet gheschiet is. Derhaluen is mijn voirgeuen heir/ dat wanneer die gerechte Christus inder eewichz na den Geest vnd Waerheyt in ons gheboren wert/ dattet een anderen Dauid na den Geest vnde Waerheyt (wie voorsecht is/ vnd Petrus betuycht heeft) sijn sal. Inden welcken dit eewich werende Koninckrijck (daer van Daniel ghesecht heeft) opgericht solde werden: vnde onuerstoort vast staende blyuen: na luydt der Schrift." This passage is not found in the earlier edition. 


\section{8 / Renaissance and Reformation}

55 This total does not included the still uncatalogued unpublished manuscript works. MF 401, for example, contains 110 handwritten tracts, treatises and letters, many of which never appeared in print. There is quite a large manuscript collection in Basel.

56 These are: Christlijcke Sendtbrieuen/Inholdende seer veele vnde verscheydene schoone Godtlijcke Vermaninghen vnde Onderrichtinghen ... (n.p, n.d.), vdL no.225 and containing letters from 1546 to 1556; Het tweede Boeck DER Christlijcker Sende-brieuen/ Inholdende veele verscheyden schoone Godtlijcke Leeringhen ... (n.p., 1611), vdL no.226 and containing letters from 1549 to 1556; and Het derde Boeck der Christelycker Sendbrieven: Inholdende veele verscheyden schoone Godlijcke Leeringhen ende Vermaningen ... (n.p., 1611), vdL no.227 and containing letters from 1551-1556, with one from 1539 and another from 1543.

57 Three of the Handbooks are known to have gone through at least two editions: Handt-Boecxken: Inholdende veele Godtlycke trouhertighe Vaderlijcke vermaningen vnde leeringen ... (n.p., n.d.), vdL no.218, revised and reprinted in 1616, vdL no.219; Dat tweede Handt-Boecxken. Den Innerlijcken Wttreck of Geestelijcke Pelgrimagie cortelyck wtghesproken (n.p., n.d.), vdL no.220, revised and reprinted 1616, vdL no.221; Dat Derde Hand-Boecxken: Inholdende verscheyden leerende Tractaten ... (n.p., 1614), vdL no.222; another edition of 1614 is vdL no.223. The fourth volume, Dat vierde Hand-Boecxken. Daer in veele Ghebeden ende Vermaningen tot bidden ... (n.p., 1626) is vdL no.224.

58 This total is based on van der Linde's count of letters in each volume.

59 See Appendix 1 and Waite, David Joris, 145-57.

60 The work was done by Joris' secretary, Heinrich van Schor. See Eugénie Droz, "Sur Quelques Traductions Françaises D'Écrits de David Joris," in Het Boek, derde reeks, XXXVII, 154-162, MF 392.

61 See Waite, "The Dutch Nobility and Anabaptism, 1535-1545," forthcoming in the Sixteenth Century Journal.

62 In 1544 Albert Pafraet was interrogated about his printing of Joris' works. He confessed to having printed four books, 200-400 copies each. J.G. de Hullu, ed., Bescheiden Betreffende de Hervorming in Overijsel (Deventer, 1897), 321-24.

63 Leonard van Dam, "Neemt waer een Gesicht," 730. See Appendix 2.

64 From the Hydeckel. Fols. 7r-126r are missing from the manuscript. I am indebted to S. Zijlstra (Groningen) for his kind assistance in providing the key to the breaking of Joris' code. The folio pages refer to the location of the code and hence the end of each letter.

65 Probably published, but available only in "David Joris sonderbare Lebensbeschreibung," 730-1.

66 unbetrieglichen.

67 Van Dam is obviously referring to the danger of detection if he went down from the attic into the main part of the house, where he might be seen by strangers or city officials.

68 Literally adern and sennen.

69 Although Joris' name is not mentioned, his identity as the man in the vision is indisputable; one of Joris' physical characteristics was a long, red beard. 
70 It is difficult to ascertain exactly where the tract ends and the anonymous biography continues, but at this point it appears that Leonard van Dam is no longer the narrator and Anonymous has taken up his story again. The account continues: "When this happened, the man was so amazed he knew not where to go, for he thought, what is the meaning of this? It was also during this time that he kept it concealed, that he did not reveal it to David. Then it happened that David was also inspired that he should go into the room (where one went to and fro, whence the first came). When he now came before the light, and another brother turned around to come towards him, a voice spoke instantly that he should kneel down, but immediately David did not allow him to do it out of concern for the others. And then a strong and loud voice spoke to him that he should be obedient. And see, he did it, regardless of whether the others might think of it as strange as he did, it had to be so." According to Anonymous, Joris also had a vision in the same room: "For in the same evening that the wonderful vision of the naked man was revealed to him [i.e., van Dam], David had a divine, glorious incident. God (it seemed to him) pulled him totally away and took David (it appeared) out of his own vision and perception, as if he were no longer the same man; indeed, he no longer recognized himself. In this vision he saw himself in Aaron's priestly nature, as a pure bride, [and] a spiritual head of the church." 